\title{
Resilience of small-scale societies' livelihoods: a framework for studying the transition from food gathering to food production
}

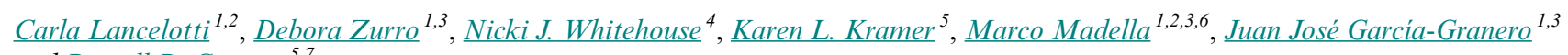 \\ and Russell D. Greaves ${ }^{5,7}$
}

\begin{abstract}
The origins of agriculture and the shift from hunting and gathering to committed agriculture is regarded as one of the major transitions in human history. Archeologists and anthropologists have invested significant efforts in explaining the origins of agriculture. A period of gathering intensification and experimentation and pursuing a mixed economic strategy seems the most plausible explanation for the transition to agriculture and provides an approach to study a process in which several nonlinear processes may have played a role. However, the mechanisms underlying the transition to full agriculture are not completely clear. This is partly due to the nature of the archeological record, which registers a practice only once it has become clearly established. Thus, points of transitions have limited visibility and the mechanisms involved in the process are difficult to untangle. The complexity of such transitions also implies that shifts can be distinctively different in particular environments and under varying historical and social conditions. In this paper we discuss some of the elements involved in the transition to food production within the framework of resilience theory. We propose a theoretical conceptual model in which the resilience of livelihood strategies lies at the intersection of three spheres: the environmental, economical, and social domains. Transitions occur when the rate of change, in one or more of these domains, is so elevated or its magnitude so large that the livelihood system is unable to bounce back to its original state. In this situation, the system moves to an alternative stable state, from one livelihood strategy to another.
\end{abstract}

Key Words: ABM; resources; social-ecological dynamics; subsistence strategies; transition to agriculture

\section{INTRODUCTION}

The adoption of agriculture is regarded as one of the major changes of the past and has been intensively studied by both archeologists and anthropologists (see, e.g., Price and Bar-Yosef 2011, Rindos 2013, Barton and An 2014). However, because of the nature of the archeological record whereby this process becomes visible only once its practice is clearly established (see Fuller 2007 for discussion), transitional phases between foraging groups and fully developed food-producing societies are much less easily unfolded (notable exceptions are represented by the work of Zvelebil and Dolukhanov 1991, and Smith 2001). Recent studies have shown that such transitional phases and the emergence of mixed subsistence economies, based on the use of both wild and domesticated animal and plant species, lasted at least several hundreds and in some cases thousands of years (Larson et al. 2014, and references therein). Further, these changes fundamentally shaped the development of agricultural societies that emerged around the world (Hayden 1990, Denham et al. 2003, Weiss et al. 2006, Kuijt and Finlayson 2009, Asouti and Fuller 2012, 2013, Fuller et al. 2012, Smith 2015). Recent methodological and technological advances, as well as an increase of archeological excavations in areas not investigated before, have produced large amounts of empirical data on forager-farmer transitions worldwide (Fuller et al. 2014, and references therein). However, the resulting interpretations are hampered by the many taphonomic problems related to archeological material, whereby differential preservation, especially of biological remains, impinges on our reconstructions of past processes. Conversely, Gremillion et al. (2014) have argued that this hyper reliance on empirical data has contributed to the rejection of general explanations on the origins of agriculture (OA) and the consequent loss of theoretically driven hypothesis testing Moreover, scholars tend to explain this transition either as a necessity, e.g., due to climate change, or as an opportunity, e.g., because domesticates offer more reliable food sources (see as Ullah et al. 2015). However, it is becoming clearer that both these mechanisms often acted in concert and at the same time or at different chronological or spatial locations and the challenge is to distinguish between these two occurrences. Recent advances in modeling and simulation approaches in archeological research (Madella et al. 2014) provide an opportunity for a detailed study of both the processes and transitions associated with agricultural production (Allaby et al. 2008, 2010, van Etten and Hijmans 2010, Ullah et al. 2015), and thus offer a formal tool to help close the gap in our understanding of the transition between huntergatherer (HG) and agro-pastoral (AP) societies.

In this paper we propose a theoretical conceptual model to study the transition to agriculture using resilience and social-ecological systems (SES) theory. This is conceived as a way to clarify the meaning of concepts and terms adopted as well as to make explicit the connections between these different concepts. The ultimate aim is to advance general theoretical understanding of the origins of agriculture through the creation of a model that will then be implemented in agent-based simulations. However, we believe that before proceeding to the implementation phase, a theoretical introduction of our proposed approach that frames transitions within resilience theory is required, and delivered in the current paper. Taken alone, none of the concepts presented here are new to archeology (see for example Redman 2005, Gronenborn et al. 2014). However, their combined use and application to understanding the resilience of livelihood strategies, is a valuable and novel contribution. The concept of livelihood strategy refers

${ }^{1}$ CaSEs - Complexity and Socio-Ecological Dynamics Research Group, ${ }^{2}$ Department of Humanities, Universitat Pompeu Fabra, Barcelona, Spain, ${ }^{3}$ Department of Archaeology and Anthropology, IMF-CSIC, Barcelona, Spain, ${ }^{4}$ School of Geography, Earth and Environmental Sciences, Plymouth University, Plymouth, UK, ${ }^{5}$ Department of Anthropology, University of Utah, Salt Lake City, Utah, USA, ${ }^{6}$ ICREA, Barcelona, Spain, ${ }^{7}$ Peabody Museum of Archeology and Ethnology, Harvard University, Cambridge, Massachusetts, USA 
to the combination of activities that people develop to achieve their subsistence goals. These usually depend on the ecological settings (environmental resources), productive strategies (economic resources) and social choices (social resources), for which we propose a parameterization (cf. Wilson 2012).

\section{Resilience theory and transitions}

The concept of resilience is used here sensu ecological resilience (Holling 1973), indicating a measure of how much a system can be perturbed without shifting to a new regime. When we talk about transitions, we intend a slow change in the system that can potentially, but not necessarily, lead to a transformation, or critical transition (Scheffer 2009). The system might gradually lose resilience until even a minor perturbation can push it over a tipping point (Scheffer 2009). Resilience theory is a particularly well-suited framework to study the nature of transitions for several reasons. First, resilience is a neutral framework, i.e., it does not have a positive or negative connotation per se but it can be one or the other depending on the circumstances (Cumming et al. 2005). Early literature tends to consider resilience as a positive state, because it is typically associated with sustainability (see a review of the use of the term resilience in Miller et al. 2010). However, these are two different, albeit sometimes related, concepts, and resilience is not always positive. Occasionally, a change at a larger scale might be beneficial and systems that do not pass a certain threshold at a lower scale might be resilient, but at the same time create problems in the surrounding environment or in the social structures that define them (Walker et al. 2004).

Another aspect of resilience theory that fits well within transition studies (as proposed by Wilson 2012) is the formalization of several adaptive cycles. Specifically, the synchronous interaction of small-and-fast, intermediate, and slow-and-large cycles seems particularly well suited to constitute a framework for studying the transition to agriculture. It is highly probable that during a longphase transition to fully committed agriculture, shifts in diet between HG and AP were common. These might have included small changes in the dependency on one type of resource or another, as well as reverses from AP to HG. Such examples are evident in the archeological record, stressing the fluid nature of food procurement and preferences toward both domesticated and wild resources, such as in areas of central and northern Europe (e.g., Bishop et al. 2009, Schibler and Jacomet 2010, Kirleis et al. 2011, Colledge and Conolly 2014, Whitehouse et al. 2014) as well as southern Europe (Antolín and Jacomet 2015, Valamoti 2015) during the transition period. Several modern HG examples also show that these strategies often are complementary and reversions from one to the other are not uncommon (e.g., Greaves and Kramer 2014). In addition, social, technological, and ecological changes may have been crucial for full reliance on agropastoralism. These changes might have ranged from the introduction of the ard and tilling technology for increasing productivity (Kerig 2013), irrigation in areas of limited rainfall (Kirch 1995, Doolittle 2014), and sophisticated storage techniques (de Saulieu and Testart 2015). Reorganization of social structures may also have been necessary to ensure food productivity and storage were reliable and available (Bar-Yosef 1998, Zapata et al. 2004). In cooler areas, more marginal to agriculture and distant from the origin centers of many cultivars, ecological and genetic changes were also required to ensure that crop seeds were suited to the local growing conditions. For instance, genetic modifications that occurred during the spread of cereal crops across Europe, allowed species to adapt to the wetter and cooler climates and shorter growing seasons of central and northern Europe compared to the crops' original regions (Jones et al. 2008, 2012). Conversely, crop failure may have been more frequent during this adaptation phase, especially considering the apparent rapidity with which agriculture spread to some of these northerly areas (Whitehouse et al. 2014).

The concept of resilience is associated with, and encompasses the concepts of adaptability, vulnerability, and transition (Wilson 2012, 2013, Callo-Concha and Ewert 2014). Adaptability can be described as the collective capacity of the actors of a system to influence resilience, i.e., high adaptation to perturbation contributes to high resilience of the system. Adaptability is used here to refer to functional outcomes and not necessarily in a Darwinian sense. Vulnerability relates to the possible changes that a system undergoes once stressed and implies that a system might be vulnerable to some perturbations but not others (Adger 2006). Transition in resilience theory is connected with the cycle of adaptive change and its four phases of transformation, growth, conservation, release, and reorganization (Holling 1987). The concepts of adaptability, vulnerability, and resilience have been largely applied to the study of agricultural systems (Callo-Concha and Ewert 2014, and references therein). In contrast, the notion of transition has been less thoroughly explored and is frequently associated with the internal transitions between stages of the adaptive cycle, rather than to change from one system to another. These transitions are governed by several fast and slow variables, the most critical and important for the system's resilience being a low rate and a low frequency of change (Walker et al. 2006, 2012).

Some researchers have criticized the expression "social resilience" because the term has been almost directly adopted from environmental sciences and psychology, without appropriate modifications for other social sciences (see Keck and Sakdapolrak 2013, Lorenz 2013, Stone-Jovicich et al. in progress, and references therein). Within archeology, resilience provides a useful conceptual framework for the study of long-term historical ecology, emphasizing the inevitability of both stability and change in social-ecological systems (Redman 2005). In other words, this framework provides an opportunity to move away from deterministic narratives of change in past societies and to explore social, economic, and ecological changes within the same sphere of investigation. Most research based on this approach has focused on the resilience of the entire social-ecological system and the relationship between society and the environment (see Butzer and Endfield 2012). Other researchers who do not explicitly use resilience theory have focused on developing the specific social mechanisms that allow societies to absorb external disturbances, e.g., promoting the inherent flexibility of the system (see Head and Fullagar 1997, Trosper 2003, Nelson et al. 2006).

\section{Why the need for another model for the transition to food production?}

The literature available on models for the OA, either using ABM or not, is vast and its full review is outside the scope of this paper. Recent and detailed reviews can be found in Barlow (2006), Winterhalder and Kennett (2006), Bettinger et al. (2010), Gremillion et al. (2014), and Zeder (2015), among others, and the 
numerous works by Tim Kohler, Michael Barton and Stephen Shennan. For what concerns the present work we find a passage of Ullah et al. work (2015:9579) critical: "Simply put, there is currently no sufficient theory to explain the nonlinear and contingent worldwide transitions from foraging to farming." We need theoretically driven hypothesis-testing and a combination of both general explanations and local narratives depending on the data used as advocated by Gremillion et al (2014). The model we propose has two important characteristics that can advance our understanding of the transition to food production: (1) it can be applied to both in situ transitions and diffusion processes; and (2) it considers a broad range of factors that collectively played a role in this transition.

Although the demic/cultural diffusion processes underlying some agricultural transitions are still debated (Fort 2012, 2015), it is now clear that the OA took a multitude of paths depending on local conditions (Abbo et al. 2010, and references therein). The ability of members of the same functional group to diversify their response to external disturbance is a key aspect of resilient livelihood strategies (Walker et al. 2006). Early agricultural systems likely enhanced the general biodiversity of ecosystems (Zeder 2008), especially through intermediate disturbance (see, for example, Colombaroli et al. 2013, Siebert and Belsky 2014). However, farming can concurrently reduce the spectrum of available foods because of selection pressures on favored plants or crop choices (Walker et al. 2006). Therefore, efforts to increase resource management efficiency might actually lead to loss of resilience of a subsistence system. The links between biodiversity loss and the maintenance of ecosystem functioning are well known (Cardinale et al. 2012), and may eventually result in water eutrophication, increasing habitat homogeneity, and species loss (Storkey et al. 2012). These, in turn, lead to ecosystem service losses and less resilient ecosystems. Monocropping with a single genotype is a modern example of extreme biodiversity loss and the end point of a trajectory that started with production of domestic cereals. From these premises, it follows that agriculturalists should have, generally speaking, lower resilience than HG (although we are aware that there are several past and present examples where agro-ecological systems show great flexibility and high dynamism). Many researchers argue that the spatial and organizational flexibility typical of hunter-gatherers or foragers can be termed resilience because it promotes a continuous readaptation of their strategies (Ames 1981, Kent 1992). Indeed, it has been hypothesized that the resilience of HG groups is greater than that of farming societies because response diversity, mobility strategies, and reliance on a wider spectrum of resources enhances resilience (Bender 1978, Winterhalder 1990, Diamond 2002, Hamilton et al. 2014 and references therein). Few examples of HG systems' failure, e.g., starvation, exist in the ethnographic record and these are mostly related to extreme climatic conditions (Jones et al. 1999, Williams et al. 2010) or the influence of a distinct population (Swift 1982, McGranaghan 2012, Friesen 2013). The model we present explores modifications introduced in the HG strategy that ultimately led to agriculture. At the same time, it also considers the weaknesses that might result in vulnerability to diffusion pressure. For example, it is unlikely that certain short-term ecological effects, such as biodiversity loss, had immediate impacts on early agriculturalists. However, they are likely to have been increasingly important in how shifts to agriculture developed through time and may also help explain situations where such transitions did not occur.

With respect to the many existing models, we believe that the one presented here contributes the following:

- Addresses the lack of recognition of the many important processes that may be modeled from current ethnographic data on mixed economies and small-scale cultivation;

- Removes the linearity that has been implied in the transition to agriculture;

- Provides an explanation for the presence of intermediate stages, or mixed economies where cultivation did not inevitably lead to agriculture;

- Provides the basis for the formalization and implementation of a model that can be used in agent-based model simulations.

Crossing one threshold, in this case reliance on foraging versus farming products, often produces a cascading effect with several other thresholds breached at different spatial and temporal scales. To focus strongly on one single domain is likely to result in missing the interactions between domain shifts (Kinzig et al. 2006). For this reason, the model we propose explicitly links subsistence change to other aspects of environment, economic strategies, and social shifts.

\section{THE MODEL}

\section{The three domains of the system}

The model follows the conceptualization proposed by Wilson (2012) that places community resilience at the intersection of three complementary domains: environmental, economic, and social. Wilson uses transition theory as an approach to the study of resilience. Here, we take an opposite point of view, linking resilience and transition theory but using the former as a framework to explain the latter. Placing resilience at the intersection of three domains has previously been suggested (see, for example, Kinzig et al. 2006 and references therein), by considering how regime shifts in one domain impact upon other domains, and then in general on the whole social-ecological system.

The model is therefore regulated by the interplay of the environmental, economic, and social resources, whereby a resilient system occurs when the three domains overlap, representing the resilient state of the SES system, or, in the present work, the capacity of a society to maintain the same livelihood strategy (Fig. 1a). The expansion of this area (representing greater or lesser resilience), can change both by modifying the overlapping part of the three areas (Fig. 1b) or the shape of one or more of the domains (Fig. 1c). The livelihood strategy ceases to be resilient when the system cannot counteract changes in the domains and when transition to a different livelihood strategy takes place (Fig. 1d). Below, is a description of how we define the domains in the model, and what factors we include in each of the three domains. Specifically, we concentrate on explaining the parameters and variables that we select as influential in the transition to food production and why we think each are important in this context. 
Table 1. Summary of the variables presented in the paper, with an indication on proxies for measuring them in past social-ecological systems.

\begin{tabular}{|c|c|c|c|}
\hline Parameter & Variable & Measure & Paleo proxies \\
\hline \multirow[t]{2}{*}{$\begin{array}{l}\text { Environmental } \\
\text { resources }\end{array}$} & $\begin{array}{l}\text { Ecosystem } \\
\text { productivity }\end{array}$ & NPP/NSP & $\begin{array}{l}\text { Micro- and macrobotanical remains } \\
\text { Micro- and macrozoological remains } \\
\text { Chemical and trace elements/nutrients } \\
\text { Temperature and moisture proxies }\end{array}$ \\
\hline & $\begin{array}{l}\text { Variability of system } \\
\text { productivity }\end{array}$ & $\begin{array}{l}\text { Temperature } \\
\text { Moisture/rainfall } \\
\text { Seasonality } \\
\text { Nutrient status }\end{array}$ & $\begin{array}{l}\text { Proxies that measure quantified temperature or that indicate } \\
\text { climate (e.g., chironomids; beetles; leaf waxes, tree rings, ice } \\
\text { cores, ocean and lake sediments, plant isotopes) }\end{array}$ \\
\hline \multirow[t]{2}{*}{ Economic resources } & Diet & Caloric intake & $\begin{array}{l}\text { Archeobotany (macro- and microremains) } \\
\text { Archeozoology } \\
\text { Stable isotopes } \\
\text { Residue analysis } \\
\text { Chemical analysis on human bones }\end{array}$ \\
\hline & Technology & $\begin{array}{l}\text { Production/extraction/preservation } \\
\text { efficiency }\end{array}$ & $\begin{array}{l}\text { Geoarcheology } \\
\text { Archeobotany (weeds) } \\
\text { Typological studies } \\
\text { Use-wear on lithics/bone tools } \\
\text { Storage structures and technologies }\end{array}$ \\
\hline \multirow[t]{2}{*}{ Social resources } & $\begin{array}{l}\text { Population } \\
\text { distribution }\end{array}$ & Demography & $\begin{array}{l}\text { Density of sites } \\
\text { Size of sites } \\
\text { Gene flow } \\
\text { Chronology/radiocarbon dates }\end{array}$ \\
\hline & Social networks & $\begin{array}{l}\text { Relationships and flows between and } \\
\text { within groups }\end{array}$ & $\begin{array}{l}\text { Patterns/distribution of the sites } \\
\text { Appearance of exotic materials (trade) }\end{array}$ \\
\hline
\end{tabular}

NPP, Net Primary Production; NSP, Net Secondary Production.

Fig. 1. Schematic representation of the model. The external circle represents the livelihood system, which comprises three domains: environmental, social, and economic resources (not named in the figure to indicate that the change is not dependent on the domain). Whenever the three domains overlap, the system can be considered resilient ( $\mathrm{a}, \mathrm{b}$, and c - green circle). The degree of resilience depends on the size of the overlapping areas: the more the three domains overlap (bigger area) the more resilient the system is. When one or more of the domains do not overlap with the others, the system is not resilient and the transition to a new system takes place ( $\mathrm{d}$ - red circle).


Considering the multiscalar, complex nature of the resilience framework, defining variables to be operationalized is extremely difficult, as also suggested by Cumming et al. (2005). In addition, when addressing resilience of social-ecological systems, which are complex systems, additional challenges are posed when approaching their formalization and parameterization because more than one attractor can play a significant role (Davidson 2010). Moreover, given the impossibility of replicating and analyzing real-world systems, it must be assumed that some level of subjectivity is inevitable in any study related to resilience of social-ecological systems. We argue that the variables selected (Table 1) are those that impact the system most, although recognize that they do not represent the entire spectrum of possible variables. We draw particular attention to the fact that it is not the absolute value of each variable that matters, but their variation and relative weight in respect to the other domains. In other words, rather than the absolute resource availability, it is the amount of variation in a particular resource and the rate of production of new resources that characterizes any particular system.

\section{Parameter 1: Environmental resources}

Humans are one of between 5 and 30 million animal species present on our planet (Erwin 1982), but use approximately $40 \%$ of the current productivity of terrestrial ecosystems (Vitousek et al. 1986). Therefore, environmental resources are fundamental in our model. We define this parameter as the biodiversity and geodiversity available for human exploitation, and we choose two specific variables, productivity and variability, because they are noncontext dependent, i.e., they can be applied to any environmental/economic setting, but can be strictly specified if 
needed, for example, looking at single resource productivity. Furthermore, this approach can accommodate different scales: single elements (e.g., temperature) or pools of elements (e.g., seasonality) and nonlinear trajectories, looking at both resilient and nonresilient systems

Variable 1: Ecosystem productivity: This represents the entire pool of resources in the system or the rate of biomass generation. A rather straightforward way to quantify the available resources is to calculate an environment's net primary production (NPP) and net secondary production (NSP).

NPP is the rate at which all the plants in an ecosystem produce net chemical energy. This rate is equal to the difference between the rate at which the plants in an ecosystem produce chemical energy (gross primary production) and the rate at which they use some of that energy during respiration. NSP is the generation of biomass of heterotrophic (consumer) organisms in a system. This is characterized by the transfer of organic material between trophic levels and represents the quantity of new tissue (mostly animal) created by food assimilation. NSP is commonly defined to include all biomass generation by heterotrophs (herbivore consumers; carnivore consumers). The NPP and NSP are wellestablished measures for energy flow and they can be calculated for any environment, with higher or lower accuracy, including those for specific resources. These resources can originate from totally anthropic environments, such as a field of wheat, or from environments where the human influence is negligible, such as a tropical forest. Gross production in animals equals the amount of biomass or energy assimilated or biomass eaten less feces.

Using NPP and/or NSP offers the opportunity to estimate the level of energy potentially co-opted by humans (Kelly 1995, Binford 2001). It also allows the evaluation of possible consequences when there is an unsustainable use of resources, such as environmental degradation and species extinctions (loss of biodiversity), and altered climate. For the purpose of our model we can use NPP, NSP, or, more useful for resources potentially available to humans, the standing crop (the measure of the biomass of a system at a single point in time; calories $/ \mathrm{m}^{2}$ ) as one of our parameters. The primary and secondary productions of an environment can be expressed as the rate of formation of new material in the environment or all biomass generated, per unit of surface and per unit of time (energy $=$ calories $/ \mathrm{m}^{2} /$ year). The difference between primary production and standing crop is crucial when, for instance, we are interested in understanding delayed investments and management of the resource. The productivity of a field of wheat can be calculated simply by the standing crop because the resource is harvested at the end of the growing season in the same year. On the other hand, the productivity of a forest or a hazelnut grove should be calculated as primary production because it must include "time" because these systems are generally managed over an extended period. Indeed, the element "time" is very important when thinking about ecosystems; and understanding how much and how fast something is happening or changing is a critical aspect for properly understanding the system under study. NPP can be calculated for past systems through current data or models of past vegetation or plant production (see for example Sugita 2007, Gaillard et al 2010). Because NSP is positively correlated with
NPP, at least for what concerns herbivores (Coe et al. 1976), NPP can be used in the model to combine two values in one measure.

Variable 2: Variability of system productivity: This variable represents inter- and intra-annual changes in a system's productivity and assesses how much and how fast a system's productivity is changing. In this case we consider changes that happen within a system's phase, because of the inherent variance of the system characteristics, rather than changes of phases. A system can be destabilized depending on the scales and tempo of the decrease in system productivity, forcing human groups to deal with fewer or diminishing resources during particular periods, which in some cases can become critical for a group's survival. The importance of variability in systems' productivity has been highlighted, for instance, by a set of simulation experiments for HG populations in semiarid environments (Balbo et al. 2014). These have shown that, independently of the scale of the climatic variability, human populations increase as the variability in yearly precipitation (VYP) decreases. Here, yearly precipitation (YP) is taken as a rough proxy of NPP, valid at least in thee specified climatic settings. Thus, the lower the interannual (annual, decadal) variation in precipitation, the better human populations perform in the simulation (population's growth). This is understandable in terms of human behavior because decreased short-term variability leads to improved predictability of resources (the system has more constant production) and continued availability from one year to the following. The opposite situation (high variance) reduces a population's growth capabilities because it requires a constant reconsideration of subsistence strategies that are dependent on the quantity of resources and their distribution in the landscape. These experiments also reveal that decadal patterns of resource availability affect reproductive strategies, i.e., the number of offspring any agent has (where the agent is a household comprising a couple and its offspring) depends on access to resources. It is interesting that similar responses are observed in current animal populations and that a higher variance of certain environmental parameters, e.g., temperature, impact the population performance (Vasseur et al. 2014). We therefore suggest that general models of ecosystem productivity should consider the amplitude and frequency of variations of ecosystems, especially in those study systems characterized by high seasonality or high fluctuations or variability in climatic parameters.

\section{Parameter 2: Economic resources}

We define this parameter as the subsistence strategy of a population, including the pool of resources that people choose to exploit among those available and by what means. Preindustrial subsistence strategies are normally divided into four major groups (Nanda and Warms 2011): (1) hunting and gathering; (2) horticulture, i.e., domestic plants and animals with low-level technology and absence of surplus; (3) pastoralism, i.e., domestic animals and animal products constitute the main resource base; and (4) agriculture, i.e., intensive or extensive cultivation of plants with high-level technologies. It now seems clear that in many cases this classification is too strict and some societies practice a mixed economy, combining elements of more than one of the abovementioned strategies (Minzenberg and Wallace 2011, Greaves and Kramer 2014). 
Variable 1: Diet: Diet, defined as the suite of resources that constitute the primary caloric intake of a community, can be traced both ethnographically and archeologically. The type and relative amounts of food items consumed can be explored ethnographically through interviews and direct observations. Past diets can be reconstructed from the archeological record using archeozoology (the study of vertebrate and invertebrate animal remains to reconstruct animal consumption and exploitation patterns), archeobotany (the study of archeological plant remains), as well as the study of human remains. These analyses offer a wealth of information on past subsistence strategies (literature on these subjects is abundant; an interesting effort to combine these techniques is represented by the work of Smith and Munro 2009). More recently, other dietary proxies, such as chemical, isotopic, and elemental signatures have been successfully used to reconstruct past diets (Fernandes et al. 2014, and references therein).

Changes in past and present subsistence strategies have been linked to climate and environmental change (e.g., Richerson et al. 2001), resource overexploitation (Williams et al. 2014), as well as modification of the social structure (e.g., McCabe et al. 2010). By modifying their diet, populations can offset the overexploitation of specific resources, but also increase their resilience. Indeed, HG are often characterized as resilient because of their diverse diet (Bender 1978) and flexible social organization (Colonese et al. 2014).

Variable 2: Technology: Technology is the means by which people access natural resources. The available technology determines the suite of resources that can be potentially procured. Technology may be viewed either as changing autochthonously in response to novel food opportunities, either environmentally generated or due to dietary shifts, or enabling new exploitive tasks through introduction. Many past archeological arguments about technological and dietary changes, especially among food producers, emphasized introductions of tools and techniques as critical (Kirch 1995, Doolittle 2014, de Saulieu and Testart 2015). Current understanding recognizes the potential complexities in identifying innovation, simple adoption, and modified use of new techniques in both archeology and ethnology. Indeed, technology and resource exploitation are suggested to be coevolutionary (see Rammel et al. 2007 for a discussion on modern complex adaptive systems).

Technological change is a key aspect of inferring subsistence shifts in archeology. Associated faunal and floral remains may not always be recovered from archeological sites to provide a secure understanding between technology and diet. Variation in tools may signal new subsistence activities, situational changes in extant dietary practices, or changes that affect resource exploitation in complex ways that can feedback into environmental availability or social organization. For example, technological innovation can drive change in the intensity with which resources are exploited, i.e., increased accessibility, reduced search, pursuit or handling time, increased return predictability (Bender 1978). For example, the introduction of firearms in Native Alaskan communities has dramatically increased the number of hunted caribou (Usher 1965).

It has been proposed that the introduction of the ox-drawn plough, whose archeological signatures can be at times studied through soil micromorphology (Lewis 2012), initiates a series of social transformations that ultimately led to intensification of production (Kerig 2013). New food processing technologies can also result in resources intensification (Wright 1994). Thus food procurement and processing artefacts may reflect changes in strategies to increase their nutritional input. Other forms of technology, such as storage, allow the unbalanced temporal production of specific resources to remain available throughout the year, mitigating risk and uncertainty in resource availability (de Saulieu and Testart 2015, and references therein). Mobility can also be considered a technological strategy to manipulate the spatial distribution of resources and maintain the stability of the system (Binford 2001, Kelly 2013, Hamilton et al. 2014, and references therein).

\section{Parameter 3: Social resources}

We define social resources as the means by which societies respond to and cope with internal and external stresses and disturbances. According to ethnography, these mechanisms emerge at different social scales including the individual, household, and community level. Archeologically, the social scale may be a much more abstract set of events because the time depth and temporal resolution of the archeological record is not equivalent to relatively short-term ethnographic observations. Although many social factors influence the ability to cope with changing and variable conditions, for simplicity, most factors are expected to filter through population distribution and social networks. Because we are exploring the transition from $\mathrm{HG}$ to AP (even if cases of reversion from AP to $\mathrm{HG}$ are not uncommon), we concentrate on the social mechanisms that primarily regulate $\mathrm{HG}$ societies.

Variable 1: Population distribution: Although the environment imposes certain constraints on population size, hunter-gatherers may adjust group numbers through various mechanisms to balance resource density with population density. The distribution of individuals, households, and groups can be managed through mobility, camp composition (Williams and Hunn 1982, Kelly 1983, 2013, Binford 2001), dispersal and postmarital residence patterns (Alvarez 2004, Marlowe 2010, Kramer and Greaves 2011), and fusion/fission dynamics (Crema 2014). Population redistribution may occur at different temporal scales, for example, daily, seasonally, or annually, and may involve the aggregation and dispersal of different group members, e.g., bachelor foraging trips, female food processing parties). At its simplest, population redistribution serves to adjust consumers and producers, and the age and sex composition of groups for the purposes of resource procurement, mating, and information exchange.

Ethnographically, population distribution has been linked to resource availability and extensive studies exist about resource availability, mobility, and population densities (Keeley 1988, Taylor 1998). For example, among Pumé mobile hunter-gatherers living on the Llanos of Venezuela, camp membership includes bilateral kin and remains stable across all seasonal moves. This appears to be a response to their marginal environment by maximizing the number of producers and to be as inclusive of male and female kin base as possible (Kramer and Greaves 2011). In contrast, among Hadza, hunter-gatherers living in the woodlands of Tanzania, individuals rotate among much smaller 
shorter term camps (Marlowe 2006). Unlike the Venezuelan Llanos, the Hadza environment has a greater availability of game, tubers, and reliable sources of honey, so that camp moves are seldom related to food shortages. Camps can include fewer producers partly because each has a greater assurance of daily foraging success (Woodburn 1972).

An archeological example is represented by the Azapa Valley (northern Chile) where Varela and Cocilovo (2002) identified changes in population distribution dynamics over a period of about 6000 years. Their study highlighted that genetic changes in the population correlate well with population mobility, increase/ decrease of endogamy in the kinship structure, and changes in the economy, i.e., beginning of plant cultivation. Population density and distribution in archeology has been inferred also through summed probability distribution of radiocarbon dates (e.g., Crema et al. 2016, Shennan and Edinborough 2007, Bamforth and Grund 2012, and references therein), through settlement pattern and distribution (Zimmermann et al. 2009), or habitable areas (see Gautney and Holliday 2015, and references therein). Some of the most recent results of this approach seem to indicate that demography had a crucial role in shaping the phase of incipient food-production in Europe (Shennan et al. 2013), although a different perspective is also emerging, that compares the demographic growth of HG to that of AP (Zahid et al. 2016).

Variable 2: Social networks: In addition to population distribution, HGs also utilize many strategies to establish social networks that link individuals with small familial units as well as across sometimes vast distances. Social networks involve obligations and responsibilities that may form among kin and nonkin for the purposes of reproduction, family formation, food and resource sharing, information exchange, protection, aggression, and other forms of cooperation. Social networks function as systems where hierarchies (elements at different scale) interact at different levels (Kohl 2008). Social networks include the number of individuals and the extent of a network (size of the network), as well as the intensity of interactions (frequency, periodicity, etc.). Because of the partiality of the archeological record, evidences for past social networks are difficult to assess. However, finding exotic materials in archeological assemblages might indicate the existence of exchange routes that possibly served as information exchange networks too (Zvelebil 2006, Otte 2009). In addition new approaches are being developed to understand population distribution across territories (Marwick 2003, Soares et al. 2010). Ethnographic data offer extensive information on social networks, which can be used to build general exchange and social networks models. Then, the complexity of the networks can be measured following specific methodologies, such as Horton-Strahler number (see an application to a social case study in Arenas et al. 2004).

Pumé hunter-gatherers, for example, frequently aggregate for allnight dances that reify group solidarity and membership across a broad social sphere (Kramer and Greaves 2016). Although food consumption does not occur during these gatherings, individuals participate by singing and dancing, activities known to promote cooperation (Adams 2004, Wiltermuth and Heath 2009). Information exchange at dances includes discussions of resource distributions, news of kin and individuals of interest for a range of economic and social reasons, and outside events that may affect local communities. These weekly dances also include storytelling and performance of healing rites. Songs and stories typically reiterate kin and affine relations across multiple generations and large distances. Rarely does a camp member not attend these events, which often are followed by foraging and hunting bouts and other cooperative activities.

Gamble (1982) was one of the first scholars to use social network theories to interpret Paleolithic art and ornaments to formalize the link between archeological objects and social alliances and interactions. Moreover, the spread of different types of ornaments has been interpreted archeologically as a mechanism for reinforcing identities and delayed reciprocity (Trubitt 2003). A way of inferring social networks from livelihood practices has been introduced by Stiner and Kuhn (2006). Their work shows that during the Late Paleolithic, the decrease in ungulates prey size, alongside changes in the mortality patterns, could be interpreted as the consequence of higher demographic pressure (Stiner et al. 1999), which in turn forced a reorganization and intensification of social networks (Stiner and Kuhn 2006).

\section{DISCUSSION}

Because the dynamics of social-ecological systems are mostly driven by humans, some authors consider adaptability mainly as a function of the social component (Walker et al. 2004). However, it is the interplay of the three domains we identify in the model (environmental, economic, and social) that influences the resilience of any particular adaptive system. Focusing too intensely on one of the three risks underestimating the effects of the others, and of their interactions. This is the reason why we have conceptualized the intersection of each domain as representing a resilience measure. Certainly, SES are complex in that the effects of the interactions are more than the sum of the single parts. For example, in our model, any changes in one of those contributing domains can affect the area of overlapping between those domains (the systems' resilience) thus producing a cascading effect in the others that ultimately affects the whole system. Environments can be affected by the economic and social behaviors of humans, and obviously environments play an important role in determining effective economic and social strategies. For example, in the transition from $\mathrm{HG}$ to AP there may be associated soil impoverishment and in some cases biodiversity loss (Denevan 1995, Haberle 2007), but the various forms of traditional landscape engineering can also be beneficial creating, in fact, higher biodiversity (Zeder 2008). On the other hand, in some ecosystems removing one element might create a cascade effect that impinges on the entire trophic system (Chapin et al. 2000). Normally, the higher the biodiversity, the more resilient the system. Generally, environmental effects are better understood or hypothesized than the diverse outcomes from changing subsistence responses of humans as economies change and social behaviors shift, making systemic resilience measures problematic. This concept has been explored in the study of livelihood strategies and it is mostly accepted that HGs, who consume a wide spectrum of food products and share and divide their foodstuff to minimize vulnerability, are more resilient than many agricultural adaptations (Bender 1978, Winterhalder 1990, Diamond 2002). 


\section{Relevance of this model to the study of the transition to agriculture}

The model we presented in this paper may be used to explain transitions in livelihood systems. In our expectations, transitions are most likely to occur when the pull of the environmental and the social domains is strong and populations do not have the possibility of mitigating it by changing some of the internal variables (technology, mobility, etc.). These may include, but are not limited to, the deliberate mixed use of wild and domesticated resources, a focus on more reliable food storage, and/or social mechanisms such as exchange and specialization (Whitehouse and Kirleis 2014, Antolín et al. 2015, García-Granero et al. 2015). As a result, the only, or most profitable, option is to completely change the subsistence strategy, i.e., the economic resources. This model offers the possibility to consider social-ecological prehistoric systems as dynamic and fluctuating. The value of this model is augmented by the additional consideration of selecting parameters that can also be examined in modern ethnographic contexts where populations exhibit stable or transitioning economies that include foraging, mixed subsistence, and agricultural reliance.

The proposed approach also removes the linearity of simply expecting most systems to lead to agricultural adaptations and provides the possibility of formalizing the model and using it for simulations. This potentially offers improved understanding of circumstances where HGs changed their strategy to include some aspects of cultivation that may or may not have led to a greater reliance on agriculture. Such instances would represent changes in the "shape" or "size" (Figs.1b and 1c) of the resilient area of the system, without the three domains separating (Fig. 1d). These cases are important to gain a better understanding of transitions from foraging to horticultural and agricultural reliance where the archeological evidence indicates that significant periods of time separate initial appearances of cultivation and the move to reliance on those foods (Allaby et al. 2008, Piperno and Pearsall 1998, Richerson et al. 2001, Smith 2001). This also means that most transitions to agriculture occur from mixed economies, not directly from hunting and gathering.

\section{$\mathrm{ABM}$ as a tool to explore resilience of livelihood strategies}

The resilience of livelihood strategies as the consequence of the dynamics between complex social and economic domains is influenced by emergent properties of societies that follow nonlinear pathways and is based on a bottom-up approach to uncertainty and change (Wilson 2012, and references therein). In this perspective, agent-based models (ABM) and simulations (ABS) represent some of the most useful tools to investigate these wider processes, and specifically in small-scale societies. Traditionally, modeling and simulation approaches are split between two different perspectives: (1) ecologically influenced or (2) oriented to artificial societies (for a synthesis on this subject, see Epstein and Axtell 1996). The first perspective is primarily interested in environmental constraints and resource exploitation and management, often neglecting the importance of human behavior. The second perspective makes use of simplified virtual societies to investigate theoretical questions, thus removing what should be a basic component of the model: the environment where human interactions take place. ABM and simulation, provides the opportunity to integrate ecological and social aspects in realistic, heterogeneous scenarios (Rubio-Campillo et al. 2012, and references therein). In addition, ABMS is able to deal with a wide range of assumptions (Balbo et al. 2014, Lake and Crema 2012) as well as with agent's decision-making processes (Francès et al. 2015), opening the possibility to investigate subsistence shifts from both a theoretical and the empirical perspective. We consider that this model incorporates a number of useful interactions to evaluate the potential for the concept of resilience to improve alternative explanatory implications behind potentially complex pathways from hunting and gathering to agricultural lifeways.

\section{CONCLUSIONS}

The model we described in this paper constitutes a first conceptualization to be used as the basis for the implementation of formal ABM and ABMS. We stress that our work on the application of these ideas is at an early stage, and present this framework in the hope that it will be useful to future research on the question of OA and, more generally, of the resilience of socialecological systems. The variables selected to explain the model can be easily converted into numerical values to be introduced in a computational model and adapted to any specific case study. The next step of the research will be the implementation of the proposed model to explore the mechanisms behind the transition to agriculture in a set of worldwide case studies. We believe that our approach can positively contribute to the challenge of understanding how this transition took place and the adaptive mechanisms that were put in place to maintain the resilience of livelihood strategies, both $\mathrm{HG}$ and AP.

\section{AUTHOR CONTRIBUTIONS}

All authors discussed the idea, the paper structure and the parameters to be included in the model. CL wrote a first draft, the general parts and the economic parameter. All other authors contributed to the general text and, more specifically, DZ and KLK contributed to the social parameters and NJW and MM to the ecological parameters.

\section{Responses to this article can be read online at: http://www.ecologyandsociety.org/issues/responses. $\mathrm{php} / 8757$}

Acknowledgments:
This paper is the result of a two-day workshop funded by ICREA
(Catalan Higher Research Institution) and organized at the ICTA
(Institute for Environmental Studies) of the Autonomous
University of Barcelona and the Department of Humanities of the
Universitat Pompeu Fabra. The workshop was cofounded by the
SimulPast project (former Spanish Ministry of Science and
Innovation, CSD2010-O0034). CL, DZ, MM, and JJGG are part
of CaSEs (Complexity and Socio-Ecological Dynamics Research
Group), a Grup de Recerca Emergent of the Generalitat de
Catalunya (SGR-e 1417). CL is currently a UPFellow; JJGG was
supported by a JAE PreDOC PhD scholarship (Spanish National
Research Council and European Social Fund) and the SimulPast
project.

This paper is the result of a two-day workshop funded by ICREA (Catalan Higher Research Institution) and organized at the ICTA University of Barcelona and the Department of Humanities of the Universitat Pompeu Fabra. The workshop was cofounded by the SimulPast project (former Spanish Ministry of Science and Innovation, CSD2010-00034). CL, DZ, MM, and JJGG are part of CaSEs (Complexity and Socio-Ecological Dynamics Research Group), a Grup de Recerca Emergent of the Generalitat de Catalunya (SGR-e 1417). CL is currently a UPFellow; JJGG was supported by a JAE PreDOC PhD scholarship (Spanish National Research Council and European Social Fund) and the SimulPast project. 


\section{LITERATURE CITED}

Abbo, S., S. Lev-Yadun, and A. Gopher. 2010. Agricultural origins: centers and noncenters; a Near Eastern reappraisal. Critical Reviews in Plant Sciences 29(5):317-328. http://dx.doi. org/10.1080/07352689.2010.502823

Adams, R. L. 2004. Archaeological study of feasting in Sulawesi, Indonesia. Journal of Anthropological Archaeology 23:56-78. http://dx.doi.org/10.1016/j.jaa.2003.10.001

Adger, W. N. 2006. Vulnerability. Global Environmental Change 16:268-281. http://dx.doi.org/10.1016/j.gloenvcha.2006.02.006

Allaby, R. G., T. A. Brown, and D. Q. Fuller. 2010. A simulation of the effect of inbreeding on crop domestication genetics with comments on the integration of archaeobotany and genetics: a reply to Honne and Heun. Vegetation History and Archaeobotany 19:151-158. http://dx.doi.org/10.1007/s00334-009-0232-8

Allaby, R. G., D. Q. Fuller, and T. A. Brown. 2008. The genetic expectations of a protracted model for the origins of domesticated crops. Proceedings of the National Academy of Sciences 105 (37):13982-13986. http://dx.doi.org/10.1073/pnas.0803780105

Alvarez, H. P. 2004. Residence groups among hunter-gatherers: a view of the claims and evidence for patrilocal bands. Pages 420-442 in B. Chapais and C. M. Berman, editors. Kinship and behavior in primates. Oxford University Press, Oxford, UK.

Ames, K. M. 1981 The evolution of social ranking on the northwest coast of North America. American Antiquity 46:789-805. http://dx.doi.org/10.2307/280106

Antolín, F., and S. Jacomet. 2015. Wild fruit use among early farmers in the Neolithic (5400-2300 cal bc) in the north-east of the Iberian Peninsula: an intensive practice? Vegetation History and Archaeobotany 24(1):19-33. http://dx.doi.org/10.1007/ s00334-014-0483-X

Antolín, F., S. Jacomet, and R. Buxó. 2015. The hard knock life. Archaeobotanical data on farming practices during the Neolithic (5400-2300 cal BC) in the NE of the Iberian Peninsula. Journal of Archaeological Science 61:90-104. http://dx.doi.org/10.1016/j. jas.2015.05.007

Arenas, A., L. Danon, A. Díaz-Guilera, P. M. Gleiser, and R. Guimerá. 2004. Community analysis in social networks. European Physical Journal B-Condensed Matter and Complex Systems 38 (2):373-380. http://dx.doi.org/10.1140/epjb/e2004-00130-1

Asouti, E., and D. Q. Fuller. 2012. From foraging to farming in the southern Levant: the development of Epipalaeolithic and Prepottery Neolithic plant management strategies. Vegetation History and Archaeobotany 21:149-162. http://dx.doi.org/10.1007/ s00334-011-0332-0

Asouti, E., and D. Q. Fuller. 2013. A contextual approach to the emergence of agriculture in Southwest Asia: reconstructing Early Neolithic plant-food production. Current Anthropology 54 (3):299-345. http://dx.doi.org/10.1086/670679

Balbo, A. L., X. Rubio-Campillo, B. Rondelli, M. Ramírez, C. Lancelotti, A. Torrano, M. Salpeteur, N. Lipovetzky, V. ReyesGarcía, C. Montañola, and M. Madella. 2014. Agent-based simulation of Holocene monsoon precipitation patterns and hunter-gatherer population dynamics in semi-arid environments.
Journal of Archaeological Method and Theory 21(2):426-446. http://dx.doi.org/10.1007/s10816-014-9203-1

Bamforth, D. B., and B. Grund. 2012. Radiocarbon calibration curves, summed probability distributions, and early Paleoindian population trends in North America. Journal of Archaeological Science 39(6):1768-1774. http://dx.doi.org/10.1016/j.jas.2012.01.017

Barlow, K. R. 2006. A formal model for predicting agriculture among the Fremont. Pages 87-102 in D. J. Kennett and B. Winterhalder, editors. Behavioral ecology and the transition to agriculture. University of California Press, Berkeley, California, USA.

Barton, L., and C.-B. An. 2014. An evaluation of competing hypotheses for the early adoption of wheat in East Asia. World Archaeology 46(5):775-798. http://dx.doi.org/10.1080/00438243.$\underline{2014.953703}$

Bar-Yosef, O. 1998. The Natufian culture in the Levant, threshold to the origins of agriculture. Evolutionary Anthropology 6 (5):159-177. http://dx.doi.org/10.1002/(sici)1520-6505(1998)6:5<159:: aid-evan $4>3.0 . \operatorname{co}: 2-7$

Bender, B. 1978. Gatherer-hunter to farmer: a social perspective. World Archaeology 10(2):204-222. http://dx.doi.org/10.1080/004$\underline{38243.1978 .9979731}$

Bettinger, R. L., L. Barton, and C. Morgan. 2010. The origins of food production in north China: a different kind of agricultural revolution. Evolutionary Anthropology: Issues, News, and Reviews 19:9-21. http://dx.doi.org/10.1002/evan.20236

Binford, L. R. 2001. Constructing frames of reference. University of California Press, Berkeley, California, USA.

Bishop, R. R., M. J. Church, and P. A. Rowley-Conwy. 2009. Cereals, fruits and nuts in the Scottish Neolithic. Proceedings of the Society of Antiquaries of Scotland 135:47-103.

Butzer, K. W., and G. H. Endfield. 2012. Critical perspectives on historical collapse. Proceedings of the National Academy of Sciences 109(10):3628-3631. http://dx.doi.org/10.1073/pnas.1114772109

Callo-Concha, D., and F. Ewert. 2014. Using the concepts of resilience, vulnerability and adaptability for the assessment and analysis of agricultural systems. Change and Adaptation in SocioEcological Systems 1(1):1-11. http://dx.doi.org/10.2478/cass-2014-0001

Cardinale, B. J., J. E. Duffy, A. Gonzalez, D. U. Hooper, C. Perrings, P. Venail, A. Narwani, G. M. Mace, D. Tilman, D. A. Wardle, A. P. Kinzig, G. C. Daily, M. Loreau, J. B. Grace, A. Larigauderie, D. S. Srivastava, and S. Naeem. 2012. Biodiversity loss and its impact on humanity. Nature 486(7401):59-67. http:// dx.doi.org/10.1038/nature11148

Chapin III, F. S., E. S. Zavaleta, V. T. Eviner, R. L. Naylor, P. M., Vitousek, H. L. Reynolds, D. U. Hooper, S. Lavorel, O. E. Sala, S. E. Hobbie, M. C. Mack, and S. Diaz. 2000. Consequences of changing biodiversity. Nature 405:234-242. http://dx.doi. org/10.1038/35012241

Coe, M. J., D. H., Cumming, and J. Phillipson. 1976. Biomass and production of large African herbivores in relation to rainfall and primary production. Oecologia 22(4):341-354. http://dx.doi. org/10.1007/bf00345312 
Colledge, S., and J. Conolly. 2014. Wild plant use in European Neolithic subsistence economies: a formal assessment of preservation bias in archaeobotanical assemblages and the implications for understanding changes in plant diet breadth. Quaternary Science Reviews 101:193-206. http://dx.doi. org/10.1016/j.quascirev.2014.07.013

Colombaroli, D., M. Beckmann, W. O. van der Knaap, P. Curdy, and W. Tinner. 2013. Changes in biodiversity and vegetation composition in the central Swiss Alps during the transition from pristine forest to first farming. Diversity and Distributions 19 (2):157-170. http://dx.doi.org/10.1111/j.1472-4642.2012.00930.x

Colonese, A. C., M. Collins, A. Lucquin, M. Eustace, Y. Hancock, R. de Almeida Rocha Ponzoni, A. Mora, C. Smith, P. DeBlasis, L. Figuti, V. Wesolowski, C. R. Plens, S. Eggers, D. Scunderlick Eloy de Farias, A. Gledhill, and O. E. Craig. 2014. Long-term resilience of late Holocene coastal subsistence system in southeastern South America. PLoS ONE 9(4):e93854. http://dx. doi.org/10.1371/journal.pone.0093854

Crema, E. R. 2014. A simulation model of fission-fusion dynamics and long-term settlement change. Journal of Archaeological Method and Theory 21(2):385-404. http://dx.doi. org/10.1007/s10816-013-9185-4

Crema, E. R., J. Habu, K. Kobayashi, and M. Madella. 2016. Summed probability distribution of $14 \mathrm{C}$ dates suggests regional divergences in the population dynamics of the Jomon period in eastern Japan. PLoS ONE 11(4):e0154809. http://dx.doi. org/10.1371/journal.pone.0154809

Cumming, G. S., G. Barnes, S. Perz, M. Schmink, K. E. Sieving, J. Southworth, M. Binford, R. D. Holt, C. Stickler, and T. Van Holt. 2005. An exploratory framework for the empirical measurement of resilience. Ecosystems 8:975-987. http://dx.doi. org/10.1007/s10021-005-0129-Z

Davidson, D. J. 2010. The applicability of the concept of resilience to social systems: some sources of optimism and nagging doubts. Society \& Natural Resources 23(12):1135-1149. http://dx.doi. org/10.1080/08941921003652940

Diamond, J. 2002. Evolution, consequences and future of plant and animal domestication. Nature 418:700-707. http://dx.doi. org/10.1038/nature01019

Denevan, W. M. 1995. Prehistoric agricultural methods as models for sustainability. Advanced Plant Pathology 11:21-43. http://dx. doi.org/10.1016/S0736-4539(06)80004-8

Denham, T. P., S. G. Haberle, C. Lentfer, R. Fullagar, J. Field, M. Therin, N. Porch, and B. Winsborough. 2003. Origins of agriculture at Kuk Swamp in the Highlands of New Guinea. Science 301:189-193. http://dx.doi.org/10.1126/science.1085255

de Saulieu, G., and A. Testart. 2015. Innovations, food storage and the origins of agriculture. Environmental Archaeology 20:314-320. http://dx.doi.org/10.1179/1749631414Y.0000000061

Doolittle, W. E. 2014. Canal irrigation in prehistoric Mexico: the sequence of technological change. University of Texas Press, Austin, Texas, USA.

Epstein, J. M., and R. L. Axtell. 1996. Growing artificial societies: social science from the bottom up. The MIT Press, Cambridge, Massachusetts, USA.
Erwin, T. L. 1982. Tropical forests: their richness in Coleoptera and other arthropod species. Coleoptera Bulletin 36:74-75.

Fernandes, R., A. R. Millard, M. Brabec, M.-J. Nadeau, and P. Grootes. 2014. Food reconstruction using isotopic transferred signals (FRUITS): a Bayesian model for diet reconstruction. PLoS ONE 9(2):e87436. http://dx.doi.org/10.1371/journal. pone.0087436

Fort, J. 2012. Synthesis between demic and cultural diffusion in the Neolithic transition in Europe. Proceedings of the National Academy of Sciences 109(46):18669-18673. http://dx.doi. org/10.1073/pnas.1200662109

Fort, J. 2015. Demic and cultural diffusion propagated the Neolithic transition across different regions of Europe. Journal of The Royal Society Interface 12(106):20150166. http://dx.doi. org/10.1098/rsif.2015.0166

Francès, G., X. Rubio-Campillo, C. Lancelotti, and M. Madella. 2015. Decision making in agent-based models. Pages 370-378 in N. Bulling, editor. Multi-agent systems: 12th European Conference, EUMAS 2014. Lecture Notes in Artificial Intelligence 8953. Springer International Publishing, New York, New York, USA. http://dx.doi.org/10.1007/978-3-319-17130-2 25

Friesen, T. M. 2013. When worlds collide: hunter-gatherer worldsystem change in the 19th Century Canadian Arctic. University of Arizona Press, Tucson, Arizona, USA.

Fuller, D. Q. 2007. Contrasting patterns in crop domestication and domestication rates: recent archaeobotanical insights from the Old World. Annals of Botany 100(5):903-924. http://dx.doi. org/10.1093/aob/mcm048

Fuller, D. Q., E. Asouti, and M. D. Purugganan. 2012. Cultivation as slow evolutionary entanglement: comparative data on rate and sequence of domestication. Vegetation History and Archaeobotany 21:131-145. http://dx.doi.org/10.1007/s00334-011-0329-8

Fuller, D. Q., T. Denham, M. Arroyo-Kalin, L. Lucas, C. J. Stevens, L. Qin, R. G. Allaby, and M. D. Purugganan. 2014. Convergent evolution and parallelism in plant domestication revealed by an expanding archaeological record. Proceedings of the National Academy of Science 111:6147-6152. http://dx.doi. org/10.1073/pnas.1308937110

Gaillard, M.-J., S. Sugita, F. Mazier, A.-K. Trondman, A. Broström, T. Hickler, J. O. Kaplan, E. Kjellström, U. Kokfelt, P. Kuneš, et al. 2010. Holocene land-cover reconstructions for studies on land cover-climate feedbacks. Climate of the Past 6:483-499. http://dx.doi.org/10.5194/cp-6-483-2010

Gamble, C. 1982. Interaction and alliance in Palaeolithic society. Man 17:92-107. http://dx.doi.org/10.2307/2802103

García-Granero, J. J., C. Gadekar, I. Esteban, C. Lancelotti, M. Madella, and P. Ajithprasad. 2015. What is on the craftsmen's menu? Plant consumption at Datrana, a 5000-year-old lithic blade workshop in North Gujarat, India. Archaeological and Anthropological Sciences 1-13.

Gautney, J. R., and T. W. Holliday. 2015. New estimations of habitable land area and human population size at the Last Glacial Maximum. Journal of Archaeological Science 58:103-112. http:// dx.doi.org/10.1016/j.jas.2015.03.028 
Greaves, R. D., and K. L. Kramer. 2014. Hunter-gatherer use of wild plants and domesticates: archaeological implications for mixed economies before agricultural intensification. Journal of Archaeological Science 41:263-271. http://dx.doi.org/10.1016/j. jas.2013.08.014

Gremillion, K. J., L. Barton, and D. R. Piperno. 2014. Particularism and the retreat from theory in the archaeology of agricultural origins. Proceedings of the National Academy of Science 111(17):6171-6177. http://dx.doi.org/10.1073/pnas.1308938110

Gronenborn, D., H.-C. Strien, S. Dietrich, and F. Sirocko. 2014. 'Adaptive cycles' and climate fluctuations: a case study from Linear Pottery Culture in western Central Europe. Journal of Archaeological Science 51:73-83. http://dx.doi.org/10.1016/j. jas.2013.03.015

Haberle, S. G. 2007. Prehistoric human impact on rainforest biodiversity in highland New Guinea. Philosophical Transactions of the Royal Society of London B: Biological Sciences 362 (1478):219-228. http://dx.doi.org/10.1098/rstb.2006.1981

Hamilton, M. J., J. Lobo, E. Rupley, H. Youn, and G. B. West. 2014. The ecology and energetics of hunter-gatherer residential mobility. Working Paper 2014-09-034, Santa Fe Institute, Santa Fe, New Mexico, USA. [online] URL: http://www.santafe.edu/ media/workingpapers/14-09-034.pdf

Hayden, B. 1990. Nimrods, piscators, pluckers, and planters: the emergence of food production. Journal of Anthropological Archaeology 9:31-69. http://dx.doi.org/10.1016/0278-4165(90) 90005-X

Head, L., and R. Fullagar. 1997. Hunter-gatherer archaeology and pastoral contact: perspectives from northwest Northern Territory. World Archaeology 28(3):418-428. http://dx.doi. org/10.1080/00438243.1997.9980356

Holling, C. S. 1973. Resilience and stability of ecological systems. Annual Review of Ecology and Systematics 4:1-23 http://dx.doi. org/10.1146/annurev.es.04.110173.000245

Holling, C. S. 1987. Simplifying the complex: the paradigms of ecological function and structure. European Journal of Operational Research 30(2):139-146. http://dx.doi.org/10.1016/0377-2217 (87)90091-9

Jones, G., H. Jones, M. P. Charles, M. K. Jones, S. Colledge, F. J. Leigh, D. Lister, L. M. J. Smith, W. Powell, and T. A. Brown. 2012. Phylogenetic analysis of Barley DNS as evidence for the spread of Neolithic agriculture through Europe. Journal of Archaeological Science 39:3230-3238. http://dx.doi.org/10.1016/ j.jas.2012.05.014

Jones, H., F. J. Leigh, I. Mackay, M. A. Bower, L. M. J. Smith, M. P. Charles, G. Jones, M. K. Jones, T. A. Brown, and W. Powell. 2008. Population based resequencing reveals that the flowering time adaptation of cultivated barley originated east of the Fertile Crescent. Molecular Biology and Evolution 25:2211-2219. http:// dx.doi.org/10.1093/molbev/msn167

Jones, T. L., G. M. Brown, L. M. Raab, J. L. McVickar, W. G. Spaulding, D. J. Kennett, A. York, and P. L. Walker. 1999. Environmental imperatives reconsidered: demographic crises in western North America during the medieval climatic anomaly. Current Anthropology 40(2):137-170. http://dx.doi.org/10.1086/200002
Keck, M., and P. Sakdapolrak. 2013. What is social resilience? Lessons learned and ways forward. Erdkunde 67(1):5-19. http:// dx.doi.org/10.3112/erdkunde.2013.01.02

Keeley, L. H. 1988. Hunter-gatherer economic complexity and "population pressure": a cross-cultural analysis. Journal of Anthropological Archaeology 7(4):373-411. http://dx.doi. org/10.1016/0278-4165(88)90003-7

Kelly, R. L. 1983. Hunter-gatherer mobility strategies. Journal of Anthropological Research 39(3):277-306. http://dx.doi.org/10.1086/ jar.39.3.3629672

Kelly, R. L. 1995. The foraging spectrum. Smithsonian Institute Press, Washington, D.C., USA.

Kelly, R. L. 2013. The lifeways of hunter-gatherers: the foraging spectrum. Cambridge University Press, Cambridge, UK. http:// dx.doi.org/10.1017/cbo9781139176132

Kent, S. 1992. The current forager controversy: real versus ideal views of hunter-gatherers. Man 27:45-70. http://dx.doi. org/10.2307/2803594

Kerig, T. 2013. Introducing economic archaeology: examples from Neolithic agriculture and Hallstatt princely tombs. Pages 13-28 in T. Kerig and A. Zimmermann, editors. Economic archaeology: from structure to performance in European archaeology Verlag DR. Rudolf Habelt GmbH, Bonn, Germany.

Kirch, P. V. 1995. The wet and the dry: irrigation and agricultural intensification in Polynesia. University of Chicago Press, Chicago, Illinois, USA.

Kirleis, W., V. D. Pillar, and H. Behling. 2011. Humanenvironment interactions in mountain rainforests: archaeobotanical evidence from central Sulawesi, Indonesia. Vegetation History and Archaeobotany 20(3):165-179. http://dx.doi.org/10.1007/ $\underline{\mathrm{s} 00334-010-0272-0}$

Kinzig, A. P., P. Ryan, M. Etienne, H. Allison, T. Elmqvist, and B. H. Walker. 2006. Resilience and regime shifts: assessing cascading effects. Ecology and Society 11(1):20. [online] URL: http://www.ecologyandsociety.org/vol11/iss1/art20/

Kohl, P. L. 2008. Shared social fields: evolutionary convergence in prehistory and contemporary practice. American Anthropologist 110(4):495-506. http://dx.doi.org/10.1111/j.1548-1433.2008.00081. $\underline{\mathrm{X}}$

Kramer, K. L., and R. D. Greaves. 2011. Postmarital residence and bilateral kin associations among hunter-gatherers. Pumé foragers living in the best of both worlds. Human Nature 22 (1):41-63. http://dx.doi.org/10.1007/s12110-011-9115-7

Kramer, K. L., and R. D. Greaves. 2016. Diversify or replace: what happens to wild foods when cultigens are introduced into hunter-gatherer diets. Pages 15-42 in B. Codding and K. L. Kramer, editors. Why forage? Hunters and gatherers living in the 21st Century. School of Advanced Research, Santa Fe, New Mexico, USA.

Kuijt, I., and B. Finlayson. 2009. Evidence for food storage and predomestication granaries 11,000 years ago in the Jordan Valley. Proceedings of the National Academy of Sciences 106 (27):10966-10970. http://dx.doi.org/10.1073/pnas.0812764106 
Lake, M. W., and E. R. Crema. 2012. The cultural evolution of adaptive-trait diversity when resources are uncertain and finite. Advances in Complex Systems 15(1-2):1150013. http://dx.doi. org/10.1142/s0219525911003323

Larson, G., D. R. Piperno, R. G. Allaby, M. D. Purugganan, L. Andersson, M. Arroyo-Kalin, L. Barton, C. Climer Vigueira, T. Denham, K. Dobney, A. N. Doust, P. Gepts, M. T. Gilbert, K. J. Gremillion, L. Lucas, L. Lukens, F. B. Marshall, K. M. Olsen, J. C. Pires, P. J. Richerson, R. Rubio de Casas, O. I. Sanjur, M. G. Thomas, and D. Q. Fuller. 2014. Current perspectives and the future of domestication studies. Proceedings of the National Academy of Science 111(17):6139-6146. http://dx.doi.org/10.1073/ pnas. 1323964111

Lewis, H. 2012. Investigating ancient tillage. An experimental and soil micromorphological study. British Archaeological Reports International Series 2388, Archaeopress, Oxford, UK.

Lorenz, D. F. 2013. The diversity of resilience: contributions from a social science perspective. Natural hazards 67(1):7-24. http://dx. doi.org/10.1007/s11069-010-9654-y

Madella, M., B. Rondelli, C. Lancelotti, A. L. Balbo, D. Zurro, X. Rubio-Campillo, and S. Stride. 2014. Introduction to simulating the past. Journal of Archaeological Method and Theory 21:251-257. http://dx.doi.org/10.1007/s10816-014-9209-8

Marlowe, F. W. 2006. Central place provisioning: the Hadza as an example. Pages 359-377 in G. Hohman, M. Robbins, and C. Boesch, editors. Feeding ecology in apes and other primates. Cambridge University Press, Cambridge, UK.

Marlowe, F. W. 2010. The Hadza: hunter-gatherers of Tanzania. University of California Press, Berkeley, California, USA.

Marwick, B. 2003. Pleistocene exchange networks as evidence for the evolution of language. Cambridge Archaeological Journal 13 (1):67-81. http://dx.doi.org/10.1017/s0959774303000040

McCabe, J. T., P. W. Leslie, and L. Deluca. 2010. Adopting cultivation to remain pastoralists: the diversification of Maasai livelihoods in northern Tanzania. Human Ecology 38:321-334. http://dx.doi.org/10.1007/s10745-010-9312-8

McGranaghan, M. 2012. Foragers on the frontiers: the/Xam Bushmen of the Northern Cape, South Africa, in the nineteenth century. Azania: Archaeological Research in Africa 47(3):408. http://dx.doi.org/10.1080/0067270x.2012.707485

Miller, F., H. Osbahr, E. Boyd, F. Thomalla, S. Bharwani, G. Ziervogel, B. Walker, J. Birkmann, S. Van der Leeuw, J. Rockström, J. Hinkel, T. Downing, C. Folke, and D. Nelson. 2010. Resilience and vulnerability: complementary or conflicting concepts? Ecology and Society 15(3):11. [online] URL: http:// www.ecologyandsociety.org/vol15/iss3/art11/

Minzenberg, E., and R. Wallace. 2011. Amazonian agriculturalists bound by subsistence hunting. Journal of Cultural Geography 28(1):99-121. http://dx.doi.org/10.1080/08873631.2011.548482

Nanda, S., and R. L. Warms. 2011. Cultural anthropology. 10th Edition. Wadsworth, Belmont, California, USA.

Nelson, M. C., M. Hegmon, S. Kulow, and K. G. Schollmeyer. 2006. Archaeological and ecological perspectives on reorganization: a case study from the Mimbres region of the U.S. Southwest. American Antiquity 71:403-432. http://dx.doi.org/10.2307/40035359

Otte, M. 2009. The Paleolithic-Mesolithic transition. Pages 537-553 in M. Camps and P. Chauhan, editors. Sourcebook of Paleolithic transitions. Springer, New York, New York, USA. http://dx.doi.org/10.1007/978-0-387-76487-0 35

Piperno, D. R., and D. M. Pearsall. 1998. The origins of agriculture in the lowland Neotropics. Academic Press, San Diego, California, USA.

Price, T. D., O. and Bar-Yosef. 2011. The origins of agriculture: new data, new ideas: an introduction to Supplement 4. Current Anthropology 52(S4):S163-S174. http://dx.doi.org/10.1086/659964

Rammel, C., S. Stagl, and H. Wilfing. 2007. Managing complex adaptive systems - a co-evolutionary perspective on natural resource management. Ecological Economics 63(1):9-21. http:// dx.doi.org/10.1016/j.ecolecon.2006.12.014

Redman, C. L. 2005. Resilience theory in archaeology. American Anthropologist 107(1):70-77. http://dx.doi.org/10.1525/aa.2005.107.1.070

Richerson, P. J., R. Boyd, and R. L. Bettinger. 2001. Was agriculture impossible during the Pleistocene but mandatory during the Holocene? A climate change hypothesis. American Antiquity 66(3):387-411. http://dx.doi.org/10.2307/2694241

Rindos, D. 2013. The origins of agriculture: an evolutionary perspective. Academic Press, San Diego, California, USA.

Rubio-Campillo, X., J. M. Cela, and F. X. Hernàndez Cardona. 2012. Simulating archaeologists? Using agent-based modeling to improve battlefield excavations. Journal of Archaeological Science 39(2):347-356. http://dx.doi.org/10.1016/j.jas.2011.09.020

Scheffer, M. 2009. Critical transitions in nature and society. Princeton University Press, Princeton, New Jersey, USA.

Schibler, J., and S. Jacomet. 2010. Short climatic fluctuations and their impact on human economies and societies: the potential of the Neolithic lake shore settlements in the Alpine foreland. Environmental Archaeology 15(2):173-182. http://dx.doi. org/10.1179/146141010x12640787648856

Shennan, S., S. S. Downey, A. Timpson, K. Edinborough, S. Colledge, T. Kerig, K. Manning, and M. G. Thomas. 2013. Regional population collapse followed initial agriculture booms in mid-Holocene Europe. Nature Communications 4:2486. http:// dx.doi.org/10.1038/ncomms3486

Shennan, S., and K. Edinborough. 2007. Prehistoric population history: from the Late Glacial to the Late Neolithic in central and northern Europe. Journal of Archaeological Science 34 (8):1339-1345. http://dx.doi.org/10.1016/j.jas.2006.10.031

Siebert, S. F., and J. M. Belsky. 2014. Historic livelihoods and land uses as ecological disturbances and their role in enhancing biodiversity: an example from Bhutan. Biological Conservation 177:82-89. http://dx.doi.org/10.1016/j.biocon.2014.06.015

Smith, A., and N. D. Munro. 2009. A holistic approach to examining ancient agriculture: a case study from the Bronze and Iron Age Near East. Current Anthropology 50(6):925-936. http:// dx.doi.org/10.1086/648316 
Smith, B. D. 2001. Low-level food production. Journal of Archaeological Science 9:1-43. http://dx.doi.org/10.1023/ A:1009436110049

Smith, B. D. 2015. A comparison of niche construction theory and diet breadth models as explanatory frameworks for the initial domestication of plants and animals. Journal of Archaeological Research 23:215-262. http://dx.doi.org/10.1007/s10814-015-9081-4

Soares, P., A. Achilli, O. Semino, W. Davies, V. Macaulay, H.-J. Bandelt, A. Torroni, and M. B. Richards 2010. The archaeogenetics of Europe. Current Biology 20(4):R174-R183. http://dx.doi.org/10.1016/j.cub.2009.11.054

Stiner, M. C., and S. L. Kuhn. 2006. Changes in the 'connectedness' and resilience of Paleolithic societies in Mediterranean ecosystems. Human Ecology 34(5):693-712. http:// dx.doi.org/10.1007/s10745-006-9041-1

Stiner, M. C., N. D. Munro, T. A. Surovell, E. Tchernov, and O. Bar-Yosef. 1999. Paleolithic population growth pulses evidenced by small animal exploitation. Science 283:190-194. http://dx.doi. org/10.1126/science.283.5399.190

Stone-Jovicich, S., K. Brown, B. Goldstein, P. Olsson, R. Plummer. In progress. Exploring social-ecological resilience through the lense of the social sciences: contributions, critical reflections and constructive debates. Ecology and Society Special Feature 99. [online] URL: http://www.ecologyandsociety.org/ issues/view.php?sf=99

Storkey, J., S. Meyer, K. S. Still, and C. Leuschner. 2012. The impact of agricultural intensification and land-use change on the European arable flora. Proceedings of the Royal Society B: Biological Sciences 279(1732):1421-1429. http://dx.doi.org/10.1098/ $\underline{\text { rspb.2011.1686 }}$

Sugita, S. 2007. Theory of quantitative reconstruction of vegetation I: pollen from large sites REVEALS regional vegetation composition. Holocene 17:229-241. http://dx.doi. org/10.1177/0959683607075837

Swift, J. 1982. The future of African hunter-gatherer and pastoral peoples. Development and Change 13(2):159-181. http://dx.doi. org/10.1111/j.1467-7660.1982.tb00116.x

Taylor, J. 1998. Measuring short-term population mobility among indigenous Australians: options and implications. Australian Geographer 29(1):125-137. http://dx.doi.org/10.1080/00049189808703207

Trosper, R. L. 2003. Resilience in pre-contact Pacific Northwest social ecological systems. Conservation Ecology 7(3):6. [online] URL: http://www.consecol.org/vol7/iss3/art6/

Trubitt, M. B. D. 2003. The production and exchange of marine shell prestige goods. Journal of Archaeological Research 11 (3):243-277. http://dx.doi.org/10.1023/A:1025028814962

Ullah, I. T., I. Kuijt, and J. Freeman. 2015. Toward a theory of punctuated subsistence change. Proceedings of the National Academy of Sciences 112(31):9579-9584. http://dx.doi. org/10.1073/pnas.1503628112

Usher, P. J. 1965. Economic basis and resource use of the Coppermine-Holman Region, N.W.T. Northern Co-ordination and Research Centre, Department of Northern Affairs and
National Resources, Ottawa, Ontario, Canada. [online] URL: http://ehrafworldcultures.yale.edu/document?id=nd08-036

Valamoti, S. M. 2015. Harvesting the 'wild'? Exploring the context of fruit and nut exploitation at Neolithic Dikili Tash, with special reference to wine. Vegetation History and Archaeobotany 24(1):35-46. http://dx.doi.org/10.1007/s00334-014-0487-6

van Etten, J., and R. J. Hijmans. 2010. A geospatial modelling approach integrating archaeobotany and genetics to trace the origin and dispersal of domesticated plants. PLOS ONE 5(8): e12060. http://dx.doi.org/10.1371/journal.pone.0012060

Varela, H. H., and A. Cocilovo. 2002. Genetic drift and gene flow in a prehistoric population of the Azapa Valley and coast, Chile. American Journal of Physical Anthropology 118:259-267. http:// dx.doi.org/10.1002/ajpa.10075

Vasseur, D. A., J. P. DeLong, B. Gilbert, H. S. Greig, C. D. G. Harley, K. S. McCann, V. Savage, T. D. Tunney, and M. I. O'Connor. 2014. Increased temperature variation poses a greater risk to species than climate warming. Proceedings of the Royal Society B 281:20132612. http://dx.doi.org/10.1098/rspb.2013.2612

Vitousek, P. M., P. R. Ehrlich, A. H. Ehrlich, and P. A. Matson. 1986. Human appropriation of the products of the photosynthesis. BioScience 36(6):368-373. http://dx.doi. org/10.2307/1310258

Walker, B., S. R. Carpenter, J. Rockström, A.-S. Crépin, and G. D. Peterson. 2012. Drivers, "slow" variables, "fast" variables, shocks, and resilience. Ecology and Society 17(3):30. http://dx.doi. org/10.5751/ES-05063-170330

Walker, B. H., L. H. Gunderson, A. P. Kinzig, C. Folke, S. R. Carpenter, and L. Schultz. 2006. A handful of heuristics and some propositions for understanding resilience in social-ecological systems. Ecology and Society 11(1):13. [online] URL: http://www. ecologyandsociety.org/vol11/iss1/art13/

Walker, B., C. S. Holling, S. R. Carpenter, and A. Kinzig. 2004. Resilience, adaptability and transformability in social-ecological systems. Ecology and Society 9(2):5. [online] URL: http://www. ecologyandsociety.org/vol9/iss2/art5

Weiss, E., M. E. Kislev, and A. Hartmann. 2006. Autonomous cultivation before domestication. Science 312:1608-1610. http:// dx.doi.org/10.1126/science.1127235

Whitehouse, N. J., and W. Kirleis. 2014. The world reshaped: practices and impacts of early agrarian societies. Journal of Archaeological Science 51:1-11 http://dx.doi.org/10.1016/j. jas.2014.08.007

Whitehouse, N. J., R. J. Schulting, M. McClatchie, P. Barratt, T. R. McLaughlin, A. Bogaard, S. Colledge, R. Marchant, J. Gaffrey, and M. J. Bunting. 2014. Neolithic agriculture on the European western frontier: the boom and bust of early farming in Ireland. Journal of Archaeological Science 51:181-205. http:// dx.doi.org/10.1016/j.jas.2013.08.009

Williams, A. N., S. Ulm, I. D. Goodwin, and M. Smith. 2010. Hunter-gatherer response to late Holocene climatic variability in northern and central Australia. Journal of Quaternary Science 25 (6):831-838. http://dx.doi.org/10.1002/jqs. 1416 
Williams, N. M., and E. S. Hunn, editors. 1982. Resource managers: North American and Australian hunter-gatherers. American Association for the Advancement of Science Selected Symposia Series. Westview, Boulder, Colorado, USA.

Williams, S. J., J. P. G. Jones, R. Annewandter, and J. M. Gibbons. 2014. Cultivation can increase harvesting pressure on overexploited plant populations. Ecological Applications 24:2050-2062. http://dx.doi.org/10.1890/13-2264.1

Wilson, G. A. 2012. Community resilience, globalization, and transitional pathways of decision-making. Geoforum 43 (6):1218-1231. http://dx.doi.org/10.1016/j.geoforum.2012.03.008

Wilson, G. A. 2013. Community resilience: path dependency, lock-in effects and transitional ruptures. Journal of Environmental Planning and Management 57(1):1-26. http://dx.doi. org/10.1080/09640568.2012.741519

Wiltermuth, S. S., and C. Heath. 2009. Synchrony and cooperation. Psychological Science 20:1-5. http://dx.doi. org/10.1111/j.1467-9280.2008.02253.X

Winterhalder, B. 1990. Open field, common pot: harvest variability and risk avoidance in agricultural and foraging societies. Pages 67-87 in E. Cashdan, editor. Risk and uncertainty in tribal and peasant economies Westview, Boulder, Colorado, USA.

Winterhalder, B., and D. J. Kennett. 2006. Behavioral ecology and the transition from hunting and gathering to agriculture. Pages 1-21 in D. J. Kennett and B. Winterhalder, editors. Behavioural ecology and the transition to agriculture. University of California Press, Berkeley, California, USA.

Woodburn, J. 1972. Ecology, nomadic movement and the composition of the local group among hunters and gatherers: an East African example and its implications. Pages 193-206 in P. J. Ucko, R. Tringham, and G. W. Dimbleby, editors. Man settlement and urbanism. Gerald Duckworth, London, UK.

Wright, K. I. 1994. Ground-stone tools and hunter-gatherer subsistence in southwest Asia: implications for the transition to farming. American Antiquity 59(2):238-263. http://dx.doi. org/10.2307/281929

Zahid, H. J., E. Robinson, and R. L. Kelly. 2016. Agriculture, population growth, and statistical analysis of the radiocarbon record. Proceedings of the National Academy of Science 113 (4):931-935. http://dx.doi.org/10.1073/pnas.1517650112

Zapata, L., L. Peña-Chocarro, G. Pérez-Jordá, and H. P. Stika. 2004. Early neolithic agriculture in the Iberian Peninsula. Journal of World Prehistory 18(4):283-325. http://dx.doi.org/10.1007/ s10963-004-5621-4

Zeder, M. A. 2008. Domestication and early agriculture in the Mediterranean Basin: origins, diffusion, and impact. Proceedings of the National Academy of Sciences 105(33):11597-11604. http:// dx.doi.org/10.1073/pnas.0801317105

Zeder, M. 2015. Core questions in domestication research. Proceedings of the National Academy of Sciences 112 (11):3191-3198. http://dx.doi.org/10.1073/pnas.1501711112
Zimmermann, A., J. Hilpert, and K. P. Wendt. 2009. Estimations of population density for selected periods between the Neolithic and AD 1800. Human Biology 81(3):357-380.

Zvelebil, M. 2006. Mobility, contact, and exchange in the Baltic Sea basin 6000-2000 BC. Journal of Anthropological Archaeology 25(2):178-192. http://dx.doi.org/10.1016/j.jaa.2005.11.003

Zvelebil, M., and P. Dolukhanov. 1991. Transition to farming in Eastern and Northern Europe. Journal of World Prehistory 5 (3):233-278. http://dx.doi.org/10.1007/BF00974991 